A'aisa's Gifts 


\section{STUDIES IN MELANESIAN ANTHROPOLOGY}

General Editors

Donald F. Tuzin

Gilbert H. Herdt

Rena Lederman

1. Michael Young, Magicians of Manumanua: Living Myth in Kalauna

2. Gilbert H. Herdt, ed., Ritualized Homosexuality in Melanesia

3. Bruce M. Knauft, Good Company and Violence: Sorcery and Social Action in a Lowland New Guinea Society

4. Kenneth E. Read, Return to the High Valley: Coming Full Circle

5. James F. Weiner, The Heart of the Pearl Shell: The Mythological Dimension of Foi Society

6. Marilyn Strathern, The Gender of the Gift: Problems with Women and Problems with Society in Melanesia

7. James G. Carrier and Achsah H. Carrier, Wage, Trade, and Exchange in Melanesia: A Manus Society in the Modern State

8. Christopher Healey, Maring Hunters and Traders: Production and Exchange in the Papua New Guinea Highlands

9. A. L. Epstein, In the Midst of Life: Affect and Ideation in the World of the Tolai

10. James G. Carrier, ed., History and Tradition in Melanesian Anthropology

11. Karen J. Brison, Just Talk: Gossip, Meetings, and Power in a Papua New Guinea Village

12. Terence E. Hays, ed., Ethnographic Presents: Pioneering Anthropologists in the Papua New Guinea Highlands

13. Michele Stephen, A'aisa's Gifts: A Study of Magic and the Self 


\section{A'aisa's Gifts}

A Study of Magic and the Self

\section{Michele Stephen}


University of California Press

Berkeley and Los Angeles, California

University of California Press

London, England

Copyright $(1) 1995$ by The Regents of the University of California

Library of Congress Cataloging-in-Publication Data

Stephen, Michele.

A'aisa's gifts : a study of magic and the self /

Michele Stephen.

p. $\mathrm{cm}$.

Includes bibliographical references and index.

ISBN 0-520-08761-5 (alk. paper). -

ISBN 0-520-08829-8 (pbk. : alk. paper)

1. Mekeo (Papua New Guinea people)-

Psychology. 2. Mekeo (Papua New Guinea

people)-Rites and ceremonies. 3. Philosophy,

Mekeo. 4. Magic, Mekeo. 5. Ethnopsychology-

Papua New Guinea. 6. Self (Philosophy)-Papua

New Guinea. 7. Dreams. 8. Papua New

Guinea-Social life and customs. I. Title.

DU740.42.S75 1995

$155.8^{\prime} 49912-\mathrm{dc} 20$

94-24807

CIP

Printed in the United States of America

$\begin{array}{lllllllll}1 & 2 & 3 & 4 & 5 & 6 & 7 & 8 & 9\end{array}$

The paper used in this publication meets the minimum requirements of American National Standard for

Information Sciences-Permanence of Paper for

Printed Library Materials, ANSI Z39.48-1984@ 
For John Stephen, the finest and truest of companions 
